\title{
Peritoneal Pseudocyst Causing Acute Abdomen as a Complication of Cronh's Disease
}

\author{
Christos Damaskos ${ }^{1, *}$, Nikolaos Garmpis², Anna Garmpi³, Aliki Liakea, Dimitrios Mantas²
}

\begin{abstract}
Peritoneal pseudocysts (PPs) in patients who are diagnosed with Crohn's disease (CD), is a rarely diagnosed entity with unknown epidemiology, etiology and pathogenesis. We present the case of a 30-year old male with known CD who presented with an acute abdomen because of a PP. PPs are developed as a complication caused in patients, suffering from mainly thee conditions. Firstly, PPs appear in patients with continuous ambulatory peritoneal dialysis (CAPD), they are also developed in patients with peritoneal trauma and finally in CD patients. Our case belongs to these three reported cases in our literature review, since it refers to a CD patient that developed PPs. He underwent emergency laparotomy and excision of the cyst, with good postoperative results. A literature review of 22 publications show that PPs often represent a diagnostic and therapeutic problem as it has a variable presentation and there are no data on what the best treatment option is - surgical excision or aspiration.
\end{abstract}

\section{KEYWORDS}

peritoneal; pseudocyst; crohn; acute; abdomen

\section{AUTHOR AFFILIATIONS}

${ }^{1}$ Renal Transplantation Unit, Laiko General Hospital, Athens, Greece

2 Second Department of Propedeutic Surgery, Laiko General Hospital, Medical School, National and Kapodistrian University of Athens, Athens, Greece

${ }^{3}$ First Department of Propedeutic Internal Medicine, Laiko General Hospital, Medical School, National and Kapodistrian University of Athens, Athens, Greece

${ }^{4}$ First Department of Pathology, Medical School, National and Kapodistrian University of Athens, Athens, Greece

* Corresponding author: Renal Transplantation Unit, Laiko General Hospital, Athens, Greece; 17 Agiou Thoma Street, 11527, Athens, Greece; e-mail:x_damaskos@yahoo.gr

Received: 1 November 2019

Accepted: 10 November 2020

Published online: 14 April 2021

Acta Medica (Hradec Králové) 2021; 64(1): 55-59

https://doi.org/10.14712/18059694.2021.10

(c) 2021 The Authors. This is an open-access article distributed under the terms of the Creative Commons Attribution License (http://creativecommons.org/licenses/by/4.0), which permits unrestricted use, distribution, and reproduction in any medium, provided the original author and source are credited. 


\section{INTRODUCTION}

Peritoneal pseudocysts (PPs) in patients who are diagnosed with Crohn's disease (CD), is a rarely diagnosed entity with unknown epidemiology, etiology and pathogenesis (1). These patients represent a diagnostic and therapeutic problem waiting to be solved. In various publications, PPs are also named as multilocular peritoneal inclusion cyst and inflammatory peritoneal cyst. PPs are reactive, fluid-filled cysts of the peritoneal serosa, often with septa in their cavity.

In this manuscript, we report on a case of a male patient with CD who presented with a PP.

\section{CASE PRESENTATION}

A 30 year-old patient with a known history of CD presented with abdominal pain and fever at the emergency department. The patient was diagnosed with CD ten years earlier affecting mainly his distal ileum for approximately $1 \mathrm{~m}$. At the time of the diagnosis his Montreal classification was A2 L1 B1. He had been under treatment with azathioprine and mesalazine in a number of occasions. No past surgery was reported.

The abdominal pain has progressively worsened during the last three weeks. The patient reported diarrhea. A week earlier, he had visited his gastroenterologist and had had an abdominal computed tomography (CT) scan. CT reported signs of inflammation of the cecum and distal ileum. It also described a pelvic cystic formation approximately $6 \mathrm{~cm}$ in diameter (Figure $1 \mathrm{~A}, \mathrm{~B}$ ).

In the emergency department he underwent an abdominal ultrasonography which indicated thickening of the distal ileum wall, presence of turbid fluid in the area of the appendix and a non-homogenous pelvic cystic mass of $11 \mathrm{~cm}$ in diameter with septa.

Due to the excruciating pain that could not be controlled with analgesics, the deteriorating general condition of the patient and the non-conclusive findings of the CT and ultrasound scans, it was decided the patient to undergo an emergency laparotomy.

Intraoperative findings consisted of cecal wall inflammation and a pelvic cyst. The cyst was drained of its clear fluid content. The abdomen presented with a diffuse inflammation. As the symptoms were totally attributed only to the cyst, it was decided not to explore the abdomen further although a rapid inspection of the abdominal cavity was undertaken to exclude other pathology. Sample of the fluid was sent for microbiology and histopathology examinations. A drain was place in the peritoneal cavity and the patient recovered uneventfully from anesthesia.

On the 5th postoperative day the patient was discharged from the hospital after an uneventful postoperative period. To date, the patient remains fit and healthy.

Histopathology reports were negative for malignancy and confirmed that the cyst wall sample was characteristic for a PP (Figure 2A, B, C). Microbiology reports were negative for bacteria or fungi growth.
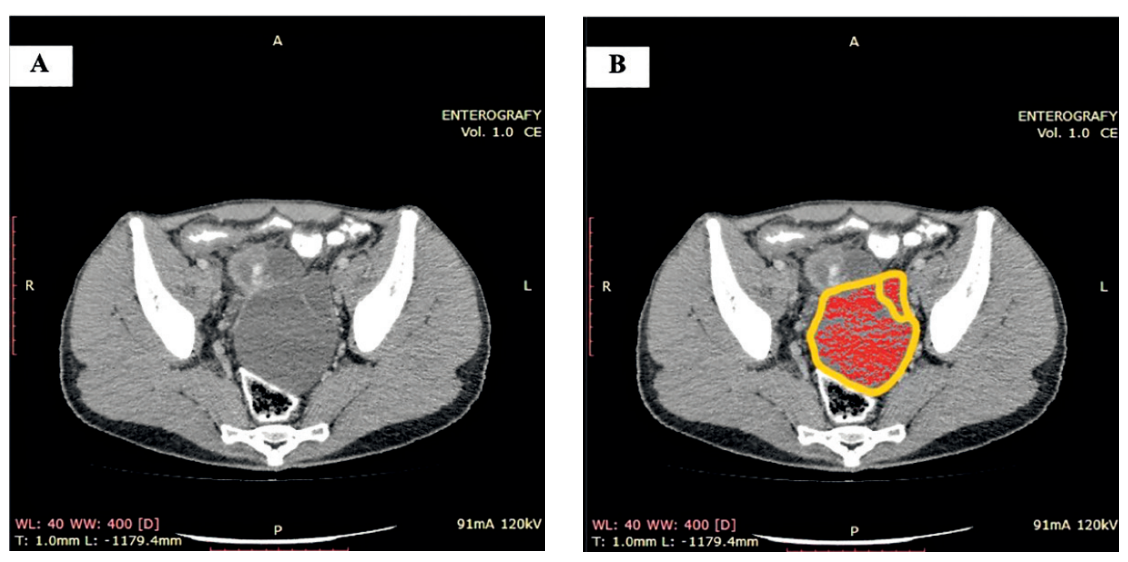

Fig. 1 A, B: Abdominal computed tomography

(CT) reported a pelvic cystic formation.
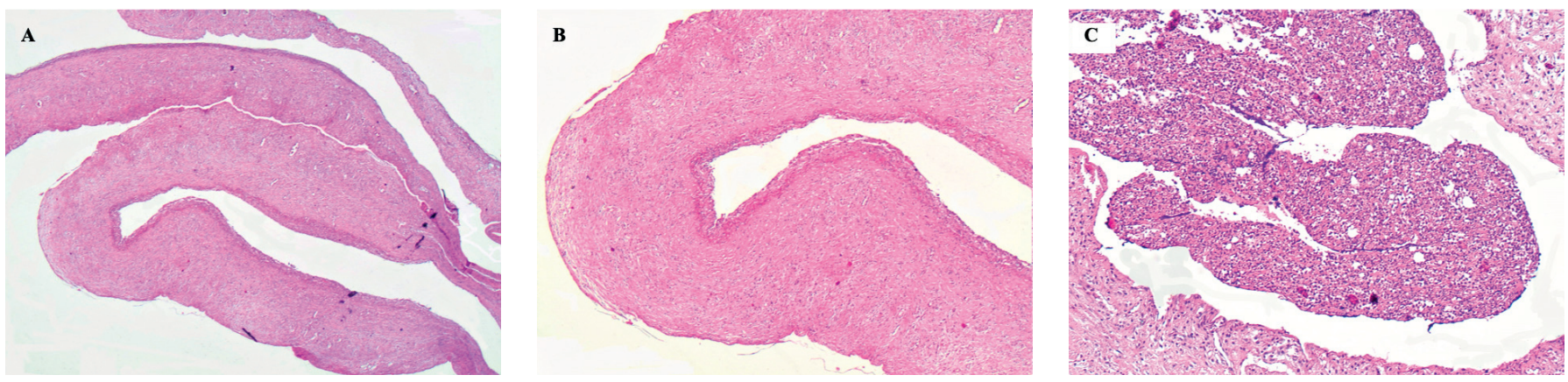

Fig. 2 A, B: Part of the thick cystic wall consisting of dense fibrous collagenous bundles, with mild vascular congestion and mild chronic inflammatory cell infiltration. No endothelial or epithelial lining is seen (Hematoxylin - Eosin, original magnification $\times 10$ and $\times 20$ respectively); C: Fragment of granulation tissue that covers the inner surface of the cyst, constisting of newly formed capillaries, mixed inflammatory cells (plasma cells, lymphocytes, neutrophils and monocytes) and cellular debris (Hematoxylin - Eosin, original magnification $\times 40$ ). 


\section{DISCUSSION}

Patients with CD who present with a PP are rarely described in the published case reports and series; only three cases are described in the 18 manuscripts that our literature search has yielded (Table 1). To date, scientific literature has produced contradictory reports regarding the epidemiology of PPs (1). The presence of PPs in patients with either ventriculo-peritoneal shunt for hydrocephalus $(2-9,21)$ or undergoing continuous ambulatory peritoneal dialysis (CAPD) $(10-13,22)$ is well described in the literature (Table 1). In the largest published case series by Veldhuis et al. (14) it is suggested that previous irritation of the peritoneum is present in over $70 \%$ of the cases, therefore PPs etiopathology might be linked to peritoneal trauma or disease. Peritoneal inflammation caused by $\mathrm{CD}$ or inflammatory bowel diseases in general are other ways of peritoneal irritation. Chronic pancreatitis or CD link to PPs may be explained by this hypothesis. Females tend to be affected more frequently, but no significant gender preponderance can be seen in Table 1. All ages seem to be equally affected although some authors report that 20-40 years of age are the peak period for PPs (15).

Tab. 1 Publications on peritoneal pseudocysts.

\begin{tabular}{|c|c|c|c|c|c|c|c|c|}
\hline Authors & $\begin{array}{l}\text { Year of pub- } \\
\text { lication }\end{array}$ & $\begin{array}{l}\text { Number } \\
\text { of cases }\end{array}$ & $\begin{array}{l}\text { Males } \\
(\%)\end{array}$ & $\begin{array}{l}\text { Median age } \\
\text { (range) }\end{array}$ & Cause & Presentation & Location & Treatment \\
\hline Latchaw et al. (5) & 1981 & NA & NA & NA & NA & NA & NA & NA \\
\hline Piercy et al. (7) & 1984 & 1 & 100 & NA & $\begin{array}{l}\text { Ventriculo-peritoneal } \\
\text { shunt }\end{array}$ & $\begin{array}{l}\text { Ureteropel- } \\
\text { vic junction } \\
\text { obstruction and } \\
\text { an enlarging right } \\
\text { upper quadrant } \\
\text { mass }\end{array}$ & $\begin{array}{l}\text { Distal } \\
\text { portion of } \\
\text { the shunt }\end{array}$ & NA \\
\hline $\begin{array}{l}\text { Joffe \& Friedberf } \\
\text { (11) }\end{array}$ & 1985 & NA & NA & NA & CAPD & NA & NA & NA \\
\hline $\begin{array}{l}\text { Singh \& Wadhwa } \\
\text { (13) }\end{array}$ & 1987 & NA & NA & NA & CAPD & NA & NA & NA \\
\hline $\begin{array}{l}\text { Grunebaum et } \\
\text { al. (4) }\end{array}$ & 1988 & 6 & NA & NA & $\begin{array}{l}\text { Ventriculo-peritoneal } \\
\text { shunt }\end{array}$ & NA & NA & NA \\
\hline Namasivayam (12) & 1991 & NA & NA & NA & NA & NA & NA & NA \\
\hline $\begin{array}{l}\text { Urbanski et al. } \\
\text { (16) }\end{array}$ & 1991 & 1 & 0 & 25 & $\begin{array}{l}\text { Previously undiagnosed } \\
\text { CD }\end{array}$ & $\begin{array}{l}\text { 10-day history of } \\
\text { lower abdominal } \\
\text { pain, diarrhea, } \\
\text { and increasing } \\
\text { abdominal pain }\end{array}$ & Pelvis & $\begin{array}{l}\text { Laparotomy } \\
\text { and excision }\end{array}$ \\
\hline Besson et al. (2) & 1995 & 22 & NA & NA & $\begin{array}{l}\text { Ventriculo-peritoneal } \\
\text { shunt }\end{array}$ & $\begin{array}{l}\text { Abdominal symp- } \\
\text { toms }\end{array}$ & NA & $\begin{array}{l}\text { Laparotomy } \\
\text { and excision } \\
(21) \text {, aspira- } \\
\text { tion (7) }\end{array}$ \\
\hline Ha et al. (10) & 1995 & NA & NA & NA & CAPD & NA & NA & NA \\
\hline Oh et al. (6) & 2001 & 11 & 0 & NA & $\begin{array}{l}\text { Ventriculo-peritoneal } \\
\text { shunt }\end{array}$ & NA & NA & $\begin{array}{l}\text { Laparo- } \\
\text { scopic cyst } \\
\text { fenestration }\end{array}$ \\
\hline $\begin{array}{l}\text { Rovlias \& Kotsou } \\
\text { (8) }\end{array}$ & 2001 & NA & NA & NA & $\begin{array}{l}\text { Ventriculo-peritoneal } \\
\text { shunt }\end{array}$ & NA & NA & NA \\
\hline Ying et al. (17) & 2007 & 10 & 0 & $42.7(35-62)$ & $\begin{array}{l}\text { History of gynecological } \\
\text { surgery }\end{array}$ & NA & Pelvis & $\begin{array}{l}\text { Laparotomy } \\
\text { and excision }\end{array}$ \\
\hline Tamura et al. (9) & 2013 & 1 & 100 & 22 & $\begin{array}{l}\text { Ventriculo-peritoneal } \\
\text { shunt }\end{array}$ & $\begin{array}{l}\text { Diffuse abdominal } \\
\text { distention }\end{array}$ & $\begin{array}{l}\text { Distal } \\
\text { portion of } \\
\text { the shunt }\end{array}$ & $\begin{array}{l}\text { Laparotomy } \\
\text { and excision }\end{array}$ \\
\hline Veldhuis et al. (14) & 2013 & 228 & 17.5 & $55(18-89)$ & $\begin{array}{l}2.6 \% \text { of patients had } \\
\text { a known history of in- } \\
\text { flammatory bowel disease } \\
\text { and/or pelvic inflamma- } \\
\text { tory disease, } 13.8 \% \text { of } \\
\text { women had a history of } \\
\text { endometriosis and } 67.1 \% \\
\text { of patients had a history } \\
\text { of abdominal surgery, } \\
\text { radiotherapy or trauma } \\
\text { involving the abdomen }\end{array}$ & NA & Various & NA \\
\hline
\end{tabular}




\begin{tabular}{|c|c|c|c|c|c|c|c|c|}
\hline Authors & $\begin{array}{l}\text { Year of pub- } \\
\text { lication }\end{array}$ & $\begin{array}{l}\text { Number } \\
\text { of cases }\end{array}$ & $\begin{array}{l}\text { Males } \\
(\%)\end{array}$ & $\begin{array}{l}\text { Median age } \\
\text { (range) }\end{array}$ & Cause & Presentation & Location & Treatment \\
\hline Ercan et al. (3) & 2014 & 1 & 0 & 22 & $\begin{array}{l}\text { Ventriculo-peritoneal } \\
\text { shunt, CAPD }\end{array}$ & $\begin{array}{l}\text { Nausea, vomiting } \\
\text { and abdominal } \\
\text { distension }\end{array}$ & NA & Aspiration \\
\hline Mazziotti et al. (1) & 2016 & 3 & 0 & $41.7(35-49)$ & $C D$ & Abdominal pain & $\begin{array}{l}\text { Left ovary, } \\
\text { small } \\
\text { bowel \& } \\
\text { urinary } \\
\text { bladder }\end{array}$ & $\begin{array}{l}\text { Cyst aspira- } \\
\text { tion }\end{array}$ \\
\hline Afroza et al. (22) & 2018 & 1 & 100 & 68 & Peritoneal dialysis & $\begin{array}{l}\text { Abdominal disten- } \\
\text { sion, abdominal } \\
\text { pain, and vomiting }\end{array}$ & Pelvis & $\begin{array}{l}\text { Medical } \\
\text { manage- } \\
\text { ment }\end{array}$ \\
\hline Cusack et al. (21) & 2019 & 1 & 100 & 37 & $\begin{array}{l}\text { A peritoneal pseudocyst } \\
\text { around a ventriculoperito- } \\
\text { neal shunt }\end{array}$ & $\begin{array}{l}\text { Distended abdo- } \\
\text { men and fatigue }\end{array}$ & Pelvis & Paracentesis \\
\hline $\begin{array}{l}\text { Damaskos et al. } \\
\text { (This study) }\end{array}$ & 2021 & 1 & 100 & 30 & $C D$ & Abdominal pain & Pelvis & $\begin{array}{l}\text { Emergency } \\
\text { laparotomy } \\
\text { \& excision }\end{array}$ \\
\hline
\end{tabular}

NA: Not available; CD: Crohn's disease; CAPD: Continuous ambulatory peritoneal dialysis.

Symptomatic PPs present with pelvic or abdominal pain and a pelvic or abdominal mass. Fever is an infrequent finding and other symptoms may occur depending on the localization of the cyst: diarrhea, vomiting, urinary problems (1). PPs are considered as a rare cause when acute abdominal pain occurs. In most cases, ascites, abdominal distention, and peritoneal signs may be present. Iinflammation or a pseudocyst is developed in $5-20 \%$ of the cases. PPs cases reported in the literature are rather heterogeneous. Most publications are single case reports while only a small number of them reporting on a larger number of patients $(14,16)$.

The macroscopic characteristics of PPs include a thin wall of less than $3 \mathrm{~mm}$ thickness, septa, no solid components, no cyst wall or septa enhancement in imaging. Apart from the lack of enhancement in imaging and the lack of solid components all other characteristics may be or not be present (14).

Some authors suggest that CA-125 is elevated in patients with pelvic PPs, but no firm data exist to support this conclusion (15). Presenting various imaging appearances, diagnosis is quite challenging. Ultrasound often set the diagnosis. Abdominal CT scan can also be used to detect PPs. However, at present, the pathological condition is monitored with the widespread use of magnetic resonance imaging (MRI) for diagnosis and follow-up examination of inflammatory bowel diseases. A technique also known with the term magnetic resonance enterography (MRE) has eased the diagnosis of both abdominal pathological findings and PPs as well (15). According to the majority of the cases presented, this method enables researchers to estimate all the useful findings such as the bowel wall thickening. In all cases, MRE allows to detect not only the presence, but also the progression of the PPs according to the treatment approach. However, biopsy is also recommended because PPs may result in squamous cell carcinoma.

To date, there is no treatment of choice. Patients that present with acute abdomen often undergo emergency laparoscopy or laparotomy. Patients with subtle clinical presentation often undergo selective excision or aspiration of the cyst fluid. The presented studies indicate that aspiration is a safe and effective nonsurgical alternative treatment for PPs in order to relieve the adverse symptoms. However, it is associated with a higher recurrence rate. Aspiration is considered as a suitable option for patients that do not want to undergo surgery, as no major complications occur. On the other hand, selective excision, being a surgical procedure, results in decreased postoperative pain and faster recovery. The complication rate is lower. However, the poor attachment of skin grafts could result in an unsuccessful outcome. There are no long-term results on the treatment of PPs, but most authors report good postoperative results and the recurrence is rare.

In the case of $C D$, treatment depends on disease severity. The first-choice treatment option is surgery, and many patients will require more than one surgery over their lifetime. However, numerous drugs have been reported to be used to treat PPs in CD. The application of medication, such as metronidazole, can manage the suppurative or perianal complications of $\mathrm{CD}$. Conservative treatment of the PPs in CD can be effective in improving symptoms, but often fails to achieve complete treatment. To conclude, according to the presented cases, successful treatment of PPS in CD patients depends on the severity of the case and the clinical appearance of the patient. Conservative treatment is a safe and feasible alternative option to manage PPS. However, in severe cases, patients require emergent hospitalization and a surgical approach.

Another cause of intraabdominal cystic formation is the peritoneal cyst, developed as a complication of chronic pancreatitis. In these cases, dangerous acute hemorrhage can take place because of a pseudocyst of the pancreas. Comparable to the case of PPs, in chronic pancreatitis a pseudocyst appears following sudden abdominal pain. The main treatment option is surgery. Meconium pseudocyst is also considered as an intraabdominal cystic 
formation in fetal bowel obstruction. The cases of prenatally diagnosed meconium peritonitis that have been reported in the literature are quite limited. Therefore, diagnosis of meconium peritonitis in the presence of a fetal intra-abdominal hyperechoic mass should be investigated (18-20).

The authors of this manuscript aim to inform physicians - especially general surgeons and gynecologists on this underreported pathology that could often lead to troublesome diagnosis and treatment. In our patient, $C D$ is considered the cause of the PP. The clinical presentation of a larger PP varies significantly depending on the organs affected and therefore physicians should have high suspicion of such pathology.

\section{CONCLUSION}

PPs represent a diagnostic and therapeutic problem as it has a variable presentation. Despite there are no data on what the best treatment option is - surgical excision or aspiration; postoperative results are good, and the recurrence is rare.

\section{CONSENT}

The patient's images have been anonymized to maintain privacy.

\section{CONFLICTS OF INTEREST}

The authors declare that they have no conflict of interest.

\section{REFERENCES}

1. Mazziotti S, D'Angelo T, Racchiusa S, Salamone I, Blandino A, Ascenti G. Peritoneal inclusion cysts in patients affected by Crohn's disease: magnetic resonance enterography findings in a case series. Clin Imaging 2016; 40(1): 152-5.

2. Besson R, Hladky JP, Dhellemmes P, Debeugny P. Peritoneal pseudocyst - ventriculo-peritoneal shunt complications. Eur J Pediatr Surg 1995; 5(4): 195-7.

3. Ercan Z, Yildirim T, Merhametsiz O, Yayar O, Haspulat A, Ayli MD. Abdominal pseudocyst development in a peritoneal dialysis patient with a ventriculoperitoneal shunt: an indication for switch to hemodialysis? Perit Dial Int 2014; 34(4): 470-1.
4. Grunebaum M, Ziv N, Kornreich L, Horev G, Lombrozo R. The sonographic signs of the peritoneal pseudocyst obstructing the ventriculo-peritoneal shunt in children. Neuroradiology 1988; 30(5): 433-8.

5. Latchaw JP Jr, Hahn JF. Intraperitoneal pseudocyst associated with peritoneal shunt. Neurosurgery 1981; 8(4): 469-72.

6. Oh A, Wildbrett P, Golub R, Yu LM, Goodrich J, Lee T. Laparoscopic repositioning of a ventriculo-peritoneal catheter tip for a sterile abdominal cerebrospinal fluid (CSF) pseudocyst. Surg Endosc 2001; 15(5): 518.

7. Piercy SL, Gregory JG, Young PH. Ventriculo-peritoneal shunt pseudocyst causing ureteropelvic junction obstruction in a child with myelomeningocele and retrocaval ureter. J Urol 1984; 132(2): 345-8.

8. Rovlias A, Kotsou S. Giant abdominal CSF pseudocyst in an adult patient 10 years after a ventriculo-peritoneal shunt. Br J Neurosurg $2001 ; 15(2): 191-2$.

9. Tamura A, Shida D, Tsutsumi K. Abdominal cerebrospinal fluid pseudocyst occurring 21 years after ventriculoperitoneal shunt placement: a case report. BMC Surg 2013; 13: 27.

10. Ha SK, Lee CH, Park CH, Lee HY, Han DS. A case of tuberculous peritonitis associated with abdominal-wall pseudocyst in a patient undergoing continuous ambulatory peritoneal dialysis (CAPD). Nephrol Dial Transplant 1995; 10(5): 706-8.

11. Joffe P, Friedberf M. Abdominal pseudocyst; the cause of repeated peritonitis during continuous ambulatory peritoneal dialysis (CAPD). Clin Nephrol 1985; 23(6): 319-20.

12. Namasivayam J, Intraperitoneal pseudocyst formation as a complication of continuous ambulatory peritoneal dialysis. Br J Radiol 1991; 64(761): 463-4.

13. Singh S, Wadhwa N. Peritonitis, pancreatitis, and infected pseudocyst in a continuous ambulatory peritoneal dialysis patient. Am J Kidney Dis 1987; 9(1): 84-6.

14. Veldhuis WB, Akin O, Goldman D, et al. Peritoneal inclusion cysts: clinical characteristics and imaging features. Eur Radiol 2013; 23(4): 1167-74.

15. Vallerie AM, Lerner JP, Wright JD, Baxi LV. Peritoneal inclusion cysts: a review. Obstet Gynecol Surv 2009; 64(5): 321-34.

16. Urbanski SR, de Lange EE, Frierson HF Jr. Magnetic resonance imaging of peritoneal pseudocyst associated with Crohn's disease: a case report. Eur J Radiol 1991; $12(1)$ : 38-40.

17. Ying W, Li Y, Zhou Y, Xie X. Cyst distortion: a new sonographic sign of peritoneal pseudocyst with regular morphology. Ultrasound Obstet Gynecol 2007; 29(2): 240-1.

18. Skok P, Sinkovic A. Acute hemorrhage into the peritoneal cavity a complication of chronic pancreatitis with pseudocyst: a case report from clinical practice. Hepatogastroenterology 1999; 46(25): 518-21.

19. Yang WT, Ho SS, Metreweli CC. Case report: antenatal sonographic diagnosis of meconium peritonitis and subsequent evolving meconium pseudocyst formation without peritoneal calcification. Clin Radiol 1997; 52(6): 477-9.

20. Adekunle A, Oluwole SF. Unusual case of diffuse intra-peritoneal calcifications associated with pancreatic pseudocyst in chronic calcific pancreatitis. East Afr Med J 1984; 61(1): 73-7.

21. Raoof S, Deng F, Cusack J. Abdomen distended by $31 \mathrm{~L}$ of cerebrospinal fluid: a peritoneal pseudocyst around a ventriculoperitoneal shunt. Lancet 2019; 394(10214): 2118.

22. Nagaraj S, Khan M, Afroza F. Recurrent Peritoneal Pseudocyst: A Rare Complication of Peritoneal Dialysis. Cureus 2018; 10(7): e3043. 